\title{
IMPACT ASSESSMENT OF TILLAGE ON CROP YIELD IN THE GUINEA SAVANNAH PART OF KWARA STATE, NIGERIA
}

\author{
Toluwalope Mubo AGAJA* \\ Department of Geography and Environmental Management, Faculty of Social Sciences, University of Ilorin, \\ P.M.B. 1515, Ilorin, Nigeria, e-mail: specialgel@yahoo.com \\ Citation : Agaja, T. M. (2019). IMPACT ASSESSMENT OF TILLAGE ON CROP YIELD IN THE \\ GUINEA SAVANNAH PART OF KWARA STATE, NIGERIA. Analele Universităţii din Oradea, Seria \\ Geografie, 29(1): 39-49. https://doi.org/10.30892/auog.291105-789
}

\begin{abstract}
Land and water resources are central focus to agriculture and are linked to environmental challenges like erosion, soil degradation, water pollution, climate change adaptation, destruction of ecosystems and habitat destruction among others. The major driver of these challenges is the use of inappropriate tillage pratices. This study investigated the environmental impact of tillage methods on crop yield and also model the impact associated with tillage methods on crop yield in the guinea savanna ecological zone, Kwara State, Nigeria. Traditional heap (T), Plough/Harrow (PH), Plough/Harrow/Ridge (PHR) and No-till tillage (NT) methods commonly used in the study area were applied to experimental plots at Unilorin Teaching and Research Farm (UTRF) and National Center for Agricultural Mechanization (NCAM), Idofian. Using Randomized Complete Block Design (RCBD), each treatment had three replicates making 12 experimental plots at each location for 2015 and 2016 planting season. Soil Water Assessment Tool (SWAT) was used to simulate the impact of the tillage methods on crop yield in watersheds over two planting seasons. The result findings reveal that crop yield $(\mathrm{kg} / \mathrm{ha})$ parameters had $\mathrm{PH}$ yield $>$ NT yield $(\mathrm{P}(0.015)<0.05)>\mathrm{T}$ yield $(\mathrm{P}(0.04)<$ $0.05)$ and $>$ PHR yield $(\mathrm{P}(0.046)<0.05)$ for UTRF and NCAM sites in 2015 while in 2016, PH yield $>\mathrm{T}$ yield $(\mathrm{P}(0.026)<0.05)>$ PHR yield $(\mathrm{P}(0.046)<0.05)$ and no statistical difference between PH and NT at both locations. Also, in the UTRF site, plant height, number of leaves, leave length and leave width explained 59.3\% and $43.3 \%$ in 2015 and 2016 of the variance in the yield of maize respectively, while in NCAM site, these variables explained $54.7 \%$ and $1.1 \%$ in 2015 and 2016 respectively. The study concludes that the different tillage methods impact on the crop yield, however, Plough/Harrow had comparatively favorable effect on the soil environment, contribution to surface runoff and crop yield. It is therefore recommended that $\mathrm{PH}$ should be adopted for a sustainable environment.
\end{abstract}

Key words: tillage, environmental impact, crop yield, agriculture

$$
* \quad * \quad * \quad * \quad * \quad *
$$

\section{INTRODUCTION}

Many studies have investigated the effect of soil tillage on crop yields, however the results are often contradictory owing to different soils and crops and using different tillage intensities.

\footnotetext{
${ }^{*}$ Corresponding Author
} 
Some authors reported sustained or increased crop productivity in conservation tillage, but usually a negative yield impact was observed depending on the duration and extent to which the conservation tillage is enacted, crop type, as well as on the climate region. The effect of tillage systems on crop yield is not uniform with all crop species, in the same manner as various soils may react differently to the same tillage practice.

According to Cook and Trlica (2016), Corn-yield reductions during the first several years after conversion to Notill from conventional tillage have been noted particularly on poorly drained soils, in Continuous Corn rotations, on certain soil types (e.g., high Organic Matter, fine texture), and in colder, wetter, and more northernly climates. However, other Notill studies have shown no distinct effect of tillage on yield and even a yield advantage in certain years indicating that relative crop performance under Notill may depend on environmental and management interactions.

Agbede et al., (2008) reported that compared with zero tillage methods, mechanized tillage methods caused reduction in plant height, leaf area, stalk girth, dry matter and grain yield and also gave lower $\mathrm{N}, \mathrm{P}, \mathrm{k}, \mathrm{Ca}$ and $\mathrm{Mg}$ content of the plant. Growth and yield parameters reduced with increased implement pass. Hence, Grain yield was reduced by 11 to $25 \%$ as a result of mechanized tillage which was not favourable to performance of sorghum.

Senjobi et al., (2013) concluded that the traditional tillage system resulted in the most favorable soil environment, for crop growth and best performance of crop followed by conventional and no-tillage system in the area studied respectively. The significant difference in yields adduced to lower bulk density, higher water holding capacity and porosity which increased plant root proliferation and optimal utilization of soil nutrients under tilled methods. Hence tillage methods have the capability to increase production while no-tillage is better under long term production for sustainable land use.

Policymakers and environmentalists believe that there is an urgent need for a change in the agricultural land management practices towards the adoption of "best management practices" (Amir and Theodor, 2012; Derpsch and Friedrich, 2010; Herman, 2010; IAASTD, 2009; FAO, 2008; IPCC, 2007). Some of such agricultural land management practices include crop rotation, alternate management practices on cultivated land, and conservation tillage practices. Besides, numerous Federal and State incentive-based programmes have been introduced in order to improve several environmental amenities. Some of the programmes are the Conservation Reserve Program (CRP), the Environmental Quality Incentive Program (EQIP), the Wetland Reserve Programs, Agricultural Development Programme (ADP) among others. The information from the literature point to the fact that tillage practices have great impact on the soil physical, chemical and biological properties, runoff amount, sediment loss, nutrient cycling (input and output), velocity, water quality and crop yield (Aina, 2011; Ohu, 2011; IAASTD, 2009; Giller et al., 2009; Mostaghimi et al., 1988; Lal, 1989). However, the type of soil, slope, precipitation amount, climatic condition, and the type of crop planted vary from place to place consequently influencing the level of impact of tillage on crop yield. This study investigated the environmental impact of tillage methods on crop yield and also modeled the impact associated with tillage methods on crop yield.

\section{The Study Area}

The study was carried out at the University of Ilorin Teaching and Research Farm, Ilorin (UTRF) and National Centre for Agricultural Mechanization (NCAM), Idofian which are located in Ilorin South Local Government Area and Ifelodun Local Government Area, Kwara State respectively. UTRF is located between latitudes $8^{\circ} 28^{\prime \prime} \mathrm{N}$ and $8^{\circ} 29^{\prime} 30^{\prime \prime} \mathrm{N}$, and between longitudes $4^{\circ}$ $3830^{\prime \prime} \mathrm{E}$ and $4^{\circ} 4030^{\prime \prime} \mathrm{E}$ NCAM is located between latitudes $8^{\circ} 22^{\prime \prime} \mathrm{N}$ and $8^{\circ} 23^{\prime \prime} \mathrm{N}$, and between longitudes $4^{\circ} 40^{\prime \prime} \mathrm{E}$ and $4^{\circ} 41^{\prime \prime} \mathrm{E}$ (figures 1). The Ilorin-Lokoja trunk A road marks the northern limit from the Oyun river bridge (Ahaneku, 1990). The climate of the study area falls within the tropical hinterland climatic zone. It is tropical and seasonal having dry season occurring between November to April, and rainy season between May and October (Mustapha, 2008). The temperature ranges from $20^{\circ} \mathrm{C}-30^{\circ} \mathrm{C}$. The vegetation is Guinea savannah grassland which is 
characterized by the presence of fire tolerant woody shrubs and trees which are biologically suited to withstand dry conditions such as locust bean trees, shear butter trees etc. The soil is ferruginous tropical soil and classified as Topic Haplustalf of Eruwa, and Odo-owa series. The parent material consists of Micaceousschists and genesis of basement complex origin which are rich in ferromagnesian minerals. Majority of the people in the study area practice subsistence farming, petty trading and are small holder farmers comprising of Yoruba, Fulani and Nupe and practice a combination of land tenure systems such as individual, rent, communal, lease hold among others. According to Ahmed (2009), food crops such as Yam, Cassava, Maize, Rice, Soya beans, Locustbeans and Groundnut are produced. Some local industries include: Garri processing, minning, Shea butter processing, trading, commerce, administration, etc.

\section{Materials and Methods}

Four treatments with three replicates were carried out using Randomized Complete Block Design (RCBD). They were treatment A (zero or no-tillage- NT), treatment B (plough and harrow$\mathrm{PH}$ ), treatment $\mathrm{C}$ (plough, harrow and ridge-PHR), and treatment $\mathrm{D}$ (heap traditional farming-T). These are conservative and conventional tillage types used in the study area. Simulation was made from the experimental plot for the entire Oyun drainage basin. Maize (Zea Mays. L. SWAM 1 variety) was planted for two farming seasons (i.e 2015 and 2016 farming year) on plot size of $5 \mathrm{~m} \mathrm{x}$ $5 \mathrm{~m}$ at spacing of $75 \mathrm{~cm}$ between rows and $50 \mathrm{~cm}$ within row. NPK (15:15:15) fertilizer was applied at 4 weeks and 8 weeks of planting, pre-emergence and post emergence herbicide for weed control were administered on the sets of the experimental plot as a normal agronomic practice.

These covered for both conventional and conservative tillage methods used in the study area. Soil Water Assessment Tool (SWAT) was also used to model the impact of tillage on crop yield through a ARCSWAT 2012.10.19 for ARCGIS software 10.2, 10.3 and 10.4. The Hydrologic Response Unit (HRU) was generated in the SWAT environment. Maps and satellite images showing the landuse types, soil, climate, relief and drainage were sourced from National Space Research and Development Agency, Nigerian Geological Agency, Kaduna State and Kwara State Bureau of Lands and Survey. Data were complemented with information from relevant books, journals, internet sources and literature.

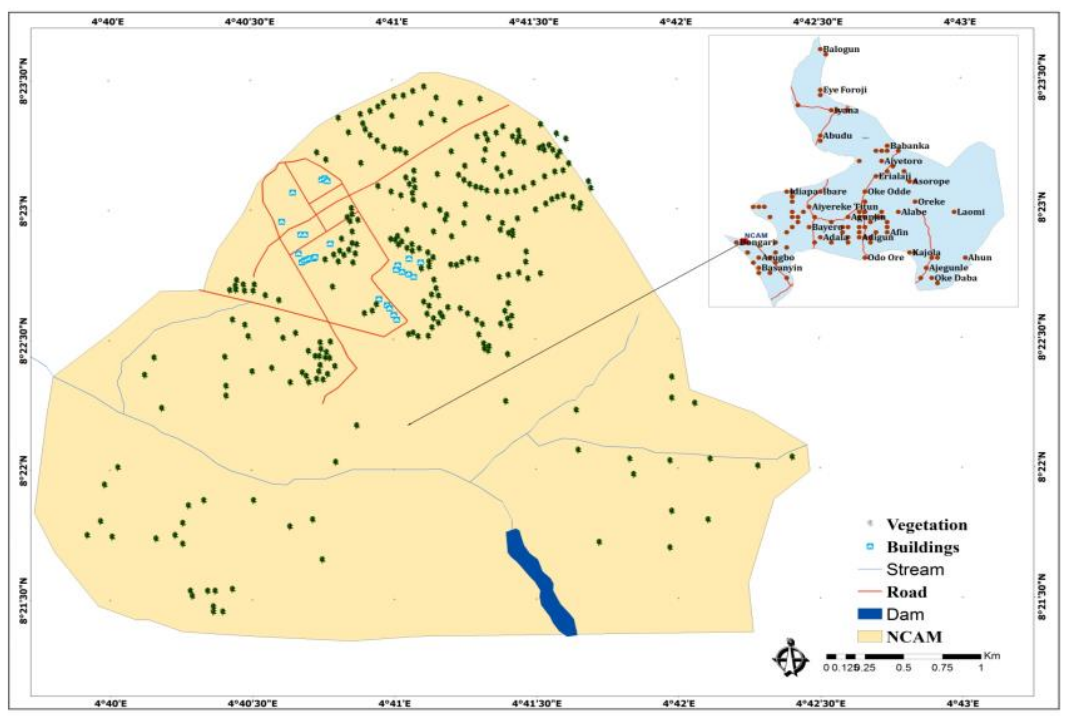

Figure 1. Map of National Center for Agricultural Mechanization (NCAM) with inset of Ifelodun Local Government Area, Kwara State, Nigeria Source: National Space Research and Development Agency (2014) 


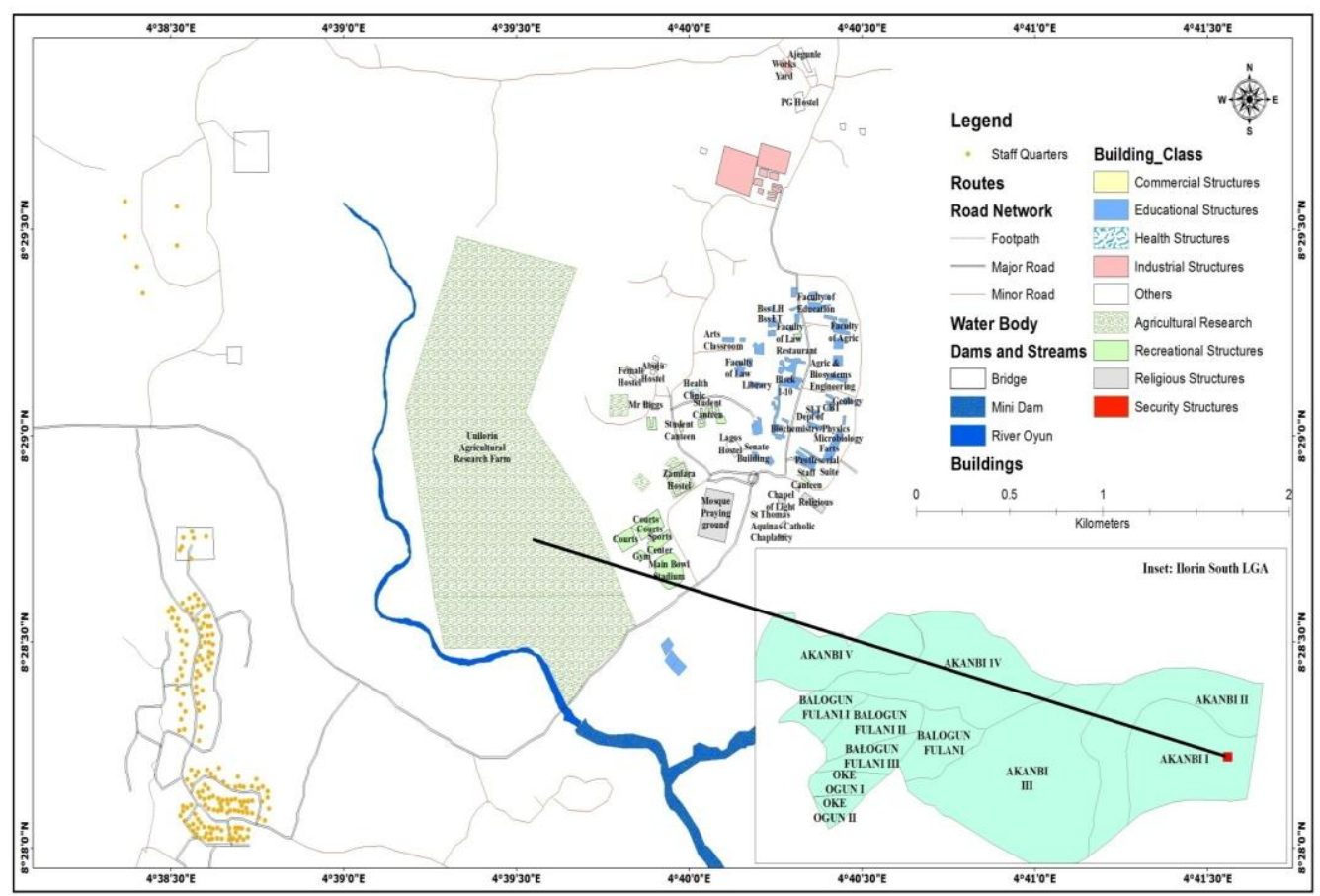

Figure 2. Map of University of Ilorin showing the Teaching Research Farm with inset map of Ilorin South Local Government Area Source: GISCleric International (2014)

\section{RESULTS AND DISCUSSION}

Agronomic Variables and Crop Yield in the University Teaching Research Farm (UTRF) and National Center for Agricultural Mechanization (NCAM) Experimental sites.

Most of the yield parameters measured was recorded highest on the Plough/Harrow and Plough/Harrow/Ridge tillage method except for the leaf area index which was recorded highest on Traditional heap and Notill tillage methods (see table 1 and 2). For instance, at highest mean value of leave width, leave length and maize height, an improved maize yield was recorded on PHR plot at the NCAM experimental site in both years while only 2015 recorded high yield on PH plot. The reverse is the case for UTRF experimental site where majority of the yield parameters were recorded highest on the Traditional heap and Notill methods. Also, leave length, number of leave area and plant height recorded an improved maize yield on Traditional heap plots in 2016 but 2015 was recorded high yield on Plough/Harrow plot. In addition, Plough/Harrow plot recorded the highest yield value for both site in 2015 although this was not the case in 2016. This implies that there is an improved maize yield in the application of $\mathrm{PH}$ compared with the other tillage types (see figure 3-8).

Table 1. Summaries of Yield Parameters for 2015 and 2016 planting season (UTRF)

(Data sources: Author's fieldwork, 2016)

\begin{tabular}{|c|c|c|c|c|c|c|c|c|c|c|c|c|}
\hline \multirow{2}{*}{ SN } & \multirow{2}{*}{$\begin{array}{l}\text { Agronomy } \\
\text { Parameters }\end{array}$} & \multirow{2}{*}{ Tillage Type } & \multicolumn{2}{|c|}{ Minimum } & \multicolumn{2}{|c|}{ Maximum } & \multicolumn{2}{|c|}{ Mean } & \multicolumn{2}{|c|}{ Std. Dev. } & \multicolumn{2}{|l|}{$\mathrm{CV}$} \\
\hline & & & 2015 & 2016 & 2015 & 2016 & 2015 & 2016 & 2015 & 2016 & 2015 & 2016 \\
\hline \multirow[t]{4}{*}{1.} & \multirow{4}{*}{$\begin{array}{l}\text { Maize } \\
\text { Height }\end{array}$} & Traditional heap & 1.65 & 1.98 & 1.95 & 2.93 & 1.81 & 2.32 & 0.15 & 0.52 & 8.29 & 22.41 \\
\hline & & Plough/Harrow & 1.72 & 1.56 & 1.86 & 2.46 & 1.78 & 1.89 & 0.07 & 0.49 & 3.93 & 25.93 \\
\hline & & Plough/Harrow/Ridging & 1.33 & 1.89 & 2.11 & 2.2 & 1.60 & 2.02 & 0.44 & 0.15 & 27.5 & 7.43 \\
\hline & & No-Till & 1.42 & 2.09 & 1.78 & 2.35 & 1.65 & 2.18 & 0.19 & 0.14 & 11.52 & 6.42 \\
\hline \multirow[t]{2}{*}{2.} & \multirow{2}{*}{$\begin{array}{l}\text { No of } \\
\text { Leaves }\end{array}$} & Traditional heap & 12 & 10 & 13 & 13 & 12.33 & 11.33 & 0.58 & 1.52 & 4.7 & 13.42 \\
\hline & & Plough/Harrow & 12 & 11 & 13 & 13 & 12.33 & 11.66 & 0.58 & 1.15 & 4.7 & 9.86 \\
\hline
\end{tabular}


Impact Assessment of Tillage on Crop Yield in the Guinea Savannah...

\begin{tabular}{|c|c|c|c|c|c|c|c|c|c|c|c|c|}
\hline & & Plough/Harrow/Ridging & 12 & 11 & 12 & 12 & 12.00 & 11.66 & 0.00 & 0.57 & 0 & 4.89 \\
\hline & & No-Till & 10 & 12 & 12 & 15 & 11.00 & 13.66 & 1.00 & 1.52 & 9.09 & 11.13 \\
\hline \multirow[t]{4}{*}{3.} & \multirow{4}{*}{$\begin{array}{l}\text { Leave } \\
\text { Length }\end{array}$} & Traditional heap & 0.76 & 0.97 & 0.9 & 1.1 & 0.85 & 1.02 & 0.08 & 0.06 & 9.41 & 5.88 \\
\hline & & Plough/Harrow & 0.71 & 0.75 & 0.81 & 1.05 & 0.78 & 0.93 & 0.05 & 0.16 & 6.41 & 17.2 \\
\hline & & Plough/Harrow/Ridging & 0.76 & 0.9 & 0.87 & 0.94 & 0.83 & 0.91 & 0.06 & 0.02 & 7.23 & 2.2 \\
\hline & & No-Till & 0.62 & 0.86 & 0.83 & 1 & 0.75 & 0.95 & 0.11 & 0.07 & 14.67 & 7.37 \\
\hline \multirow[t]{4}{*}{4.} & \multirow{4}{*}{ Leaf width } & Traditional heap & 4.13 & 4 & 4.88 & 5 & 4.38 & 4.33 & 0.43 & 0.57 & 9.82 & 13.16 \\
\hline & & Plough/Harrow & 4.05 & 3.5 & 4.41 & 4.3 & 4.21 & 3.93 & 0.18 & 0.40 & 4.28 & 10.18 \\
\hline & & Plough/Harrow/Ridging & 4.23 & 4 & 4.59 & 5 & 4.37 & 4.66 & 0.19 & 0.57 & 4.35 & 12.23 \\
\hline & & No-Till & 4.13 & 3.3 & 4.75 & 4 & 4.42 & 3.6 & 0.31 & 0.36 & 7.01 & 10.00 \\
\hline \multirow[t]{4}{*}{5.} & \multirow{4}{*}{$\begin{array}{l}\text { Crop } \\
\text { Yield } \\
\text { (tones/ha) }\end{array}$} & Traditional heap & 1000 & 1040 & 1800 & 1600 & 1400 & 1253.33 & 400 & 302.87 & 28.57 & 24.17 \\
\hline & & Plough/Harrow & 2000 & 640 & 2600 & 1280 & 2333.33 & 880 & 305.51 & 348.71 & 13.09 & 39.63 \\
\hline & & Plough/Harrow/Ridging & 1200 & 760 & 2000 & 920 & 1533.33 & 826.66 & 416.33 & 83.26 & 27.15 & 10.07 \\
\hline & & No-Till & 1000 & 440 & 1400 & 720 & 1200 & 586.66 & 200 & 140.47 & 16.67 & 23.94 \\
\hline \multirow{4}{*}{6.} & \multirow{4}{*}{$\begin{array}{l}\text { Leave } \\
\text { Area } \\
\text { Index }\end{array}$} & Traditional heap & 1.91 & 2.52 & 2.21 & 2.85 & 2.01 & 2.67 & .169 & .166 & 8.40 & 6.21 \\
\hline & & Plough/Harrow & 1.80 & 1.81 & 2.46 & 2.52 & 2.19 & 2.19 & .348 & .358 & 15.89 & 16.34 \\
\hline & & Plough/Harrow/Ridging & 1.72 & 1.11 & 2.12 & 1.85 & 1.92 & 1.35 & .201 & .422 & 10.46 & 31.25 \\
\hline & & No-Till & 2.11 & 2.46 & 2.69 & 3.10 & 2.48 & 2.84 & .327 & .336 & 13.18 & 11.83 \\
\hline
\end{tabular}

KEY- T-traditional heap, PH-plough/harrow, NT-No-till, PHR-Plough/harrow/ridge, CV- coefficient of variation, UTRF -Unilorin Teaching and Research Farm plots.

Table 2. Summaries of Yield Parameters on NCAM site for 2015 and 2016 planting season (Data sources: Author's fieldwork, 2016)

\begin{tabular}{|c|c|c|c|c|c|c|c|c|c|c|c|c|}
\hline \multirow[t]{2}{*}{ SN } & \multirow[t]{2}{*}{$\begin{array}{l}\text { Agronomy } \\
\text { Parameters } \\
\end{array}$} & \multirow[t]{2}{*}{ Tillage Type } & \multicolumn{2}{|c|}{ Minimum } & \multicolumn{2}{|c|}{ Maximum } & \multicolumn{2}{|l|}{ Mean } & \multicolumn{2}{|c|}{ Std. Dev. } & \multicolumn{2}{|l|}{$\mathrm{CV}$} \\
\hline & & & 2015 & 2016 & 2015 & 2016 & 2015 & 2016 & 2015 & 2016 & 2015 & 2016 \\
\hline \multirow{4}{*}{1} & \multirow{4}{*}{$\begin{array}{l}\text { Maize } \\
\text { Height }\end{array}$} & Traditional heap & 1.59 & 2.04 & 1.76 & 2.2 & 1.69 & 2.10 & 0.09 & 0.08 & 5.33 & 3.81 \\
\hline & & Plough/Harrow & 1.6 & 1.98 & 2.01 & 2.41 & 1.82 & 2.19 & 0.21 & 0.21 & 11.54 & 9.59 \\
\hline & & Plough/Harrow/Ridging & 1.57 & 1.9 & 1.85 & 2.28 & 1.67 & 2.11 & 0.16 & 0.19 & 9.58 & 9 \\
\hline & & No-Till & 1.53 & 1.06 & 1.68 & 1.29 & 1.58 & 1.15 & 0.08 & 0.11 & 5.06 & 9.57 \\
\hline \multirow{4}{*}{2} & \multirow{4}{*}{$\begin{array}{l}\text { No of } \\
\text { Leaves }\end{array}$} & Traditional heap & 10 & 12 & 12 & 13 & 11.33 & 12.33 & 1.15 & 0.57 & 10.15 & 4.62 \\
\hline & & Plough/Harrow & 11 & 11 & 12 & 13 & 11.33 & 12 & 0.58 & 1 & 5.12 & 8.33 \\
\hline & & Plough/Harrow/Ridging & 12 & 12 & 12 & 13 & 12 & 12.33 & 0.05 & 0.57 & 0.42 & 4.62 \\
\hline & & No-Till & 10 & 8 & 11 & 9 & 10.33 & 8.33 & 0.05 & 0.57 & 0.48 & 6.84 \\
\hline \multirow{4}{*}{3} & \multirow{4}{*}{$\begin{array}{l}\text { Leave } \\
\text { Length }\end{array}$} & Traditional heap & 0.72 & 0.8 & 0.81 & 0.95 & 0.75 & 0.86 & 0.13 & 0.07 & 17.33 & 8.14 \\
\hline & & Plough/Harrow & 0.75 & 0.69 & 0.84 & 0.82 & 0.81 & 0.77 & 0.04 & 0.07 & 4.94 & 9.09 \\
\hline & & Plough/Harrow/Ridging & 0.79 & 0.82 & 1.03 & 0.96 & 0.89 & 0.89 & 0.13 & 0.07 & 14.61 & 7.87 \\
\hline & & No-Till & 0.71 & 0.59 & 0.78 & 0.82 & 0.75 & 0.68 & 0.04 & 0.11 & 5.33 & 16.18 \\
\hline \multirow{4}{*}{4} & \multirow[t]{4}{*}{ Leaf width } & Traditional heap & 3.48 & 4 & 3.63 & 4.2 & 3.55 & 4.13 & 0.08 & 0.11 & 2.25 & 2.66 \\
\hline & & Plough/Harrow & 3.2 & 3.5 & 3.9 & 4.1 & 3.60 & 3.76 & 0.36 & 0.30 & 10 & 7.98 \\
\hline & & Plough/Harrow/Ridging & 3.48 & 4 & 4.23 & 4.4 & 3.76 & 4.23 & 0.41 & 0.20 & 10.9 & 4.73 \\
\hline & & No-Till & 3.23 & 2.3 & 3.63 & 3 & 3.40 & 2.6 & 0.21 & 0.36 & 6.18 & 13.85 \\
\hline \multirow{4}{*}{5} & \multirow{4}{*}{$\begin{array}{l}\text { Crop } \\
\text { Yield } \\
\text { (tones/ha) }\end{array}$} & Traditional heap & 400 & 440 & 600 & 800 & 466.67 & 586.66 & 115.47 & 189.03 & 24.74 & 32.22 \\
\hline & & Plough/Harrow & 1200 & 600 & 1800 & 640 & 1400 & 613.33 & 346.41 & 23.09 & 24.74 & 3.76 \\
\hline & & Plough/Harrow/Ridging & 400 & 680 & 800 & 800 & 566.67 & 733.33 & 208.17 & 61.10 & 36.74 & 8.33 \\
\hline & & No-Till & 200 & 360 & 1000 & 800 & 733.33 & 520 & 461.88 & 243.31 & 62.98 & 46.79 \\
\hline \multirow{4}{*}{6} & \multirow{4}{*}{$\begin{array}{l}\text { Leave } \\
\text { Area } \\
\text { Index }\end{array}$} & Traditional heap & 2.35 & 2.91 & 3.29 & 4.13 & 2.80 & 3.34 & .471 & .677 & 16.82 & 20.26 \\
\hline & & Plough/Harrow & 2.16 & 1.97 & 2.68 & 3.39 & 2.45 & 2.78 & .270 & .732 & 11.02 & 26.33 \\
\hline & & Plough/Harrow/Ridging & 1.92 & 2.13 & 2.81 & 2.97 & 2.48 & 2.57 & .492 & .423 & 19.83 & 16.45 \\
\hline & & No-Till & 2.41 & 2.70 & 2.96 & 3.53 & 2.72 & 3.200 & .283 & .439 & 10.40 & 13.71 \\
\hline
\end{tabular}

KEY- T-traditional heap, PH-plough/harrow, NT-No-till, PHR-Plough/harrow/ridge, CV- coefficient of variation, NCAM- National Centre for Agricultural Mechanization experimental plot

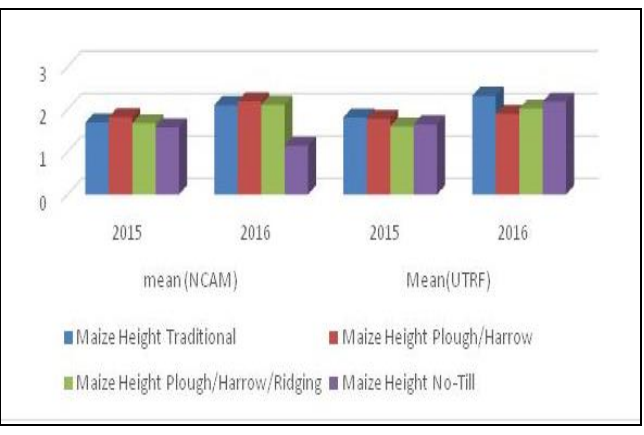

Figure 3. Mean Maize Height on Different Tillage Type in UTRF and NCAM Experimental Plot for 2015 and 2016 planting Source: Author's fieldwork (2016)

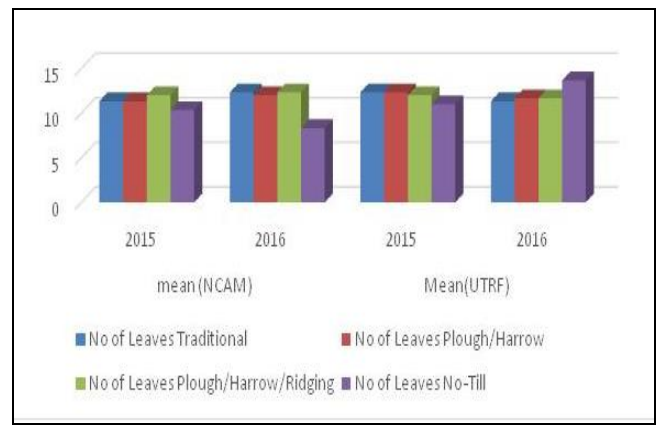

Figure 4. Mean Leave Number on Different Tillage Type in UTRF and NCAM Experimental Plot for 2015 and 2016 planting season Source: Author's fieldwork (2016) 


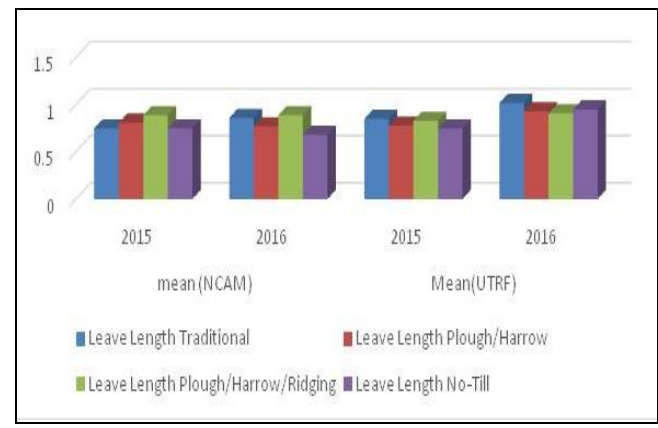

Figure 5. Mean Leave Length on Different Tillage Type in UTRF and NCAM Experimental Site for 2015 and 2016 planting season Source: Author's fieldwork (2016)

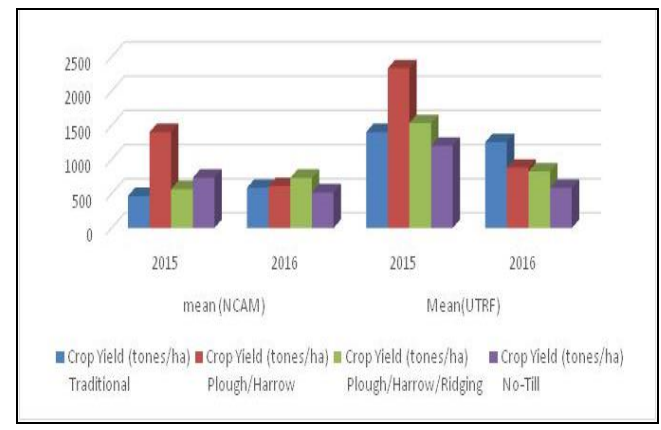

Figure 7. Mean Crop Yield on Different Tillage Type in UTRF and NCAM Experimental Site for 2015 and 2016 planting season Source: Author's fieldwork (2016)

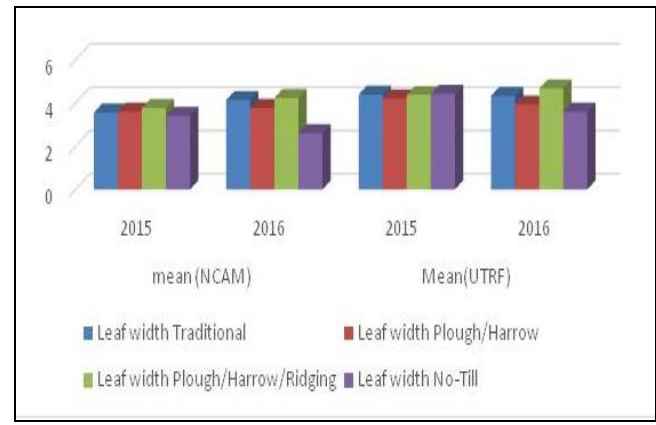

Figure 6. Mean Leave Width on Different Tillage Type in UTRF and NCAM Experimental Site for 2015 and 2016 planting season Source: Author's fieldwork (2016)

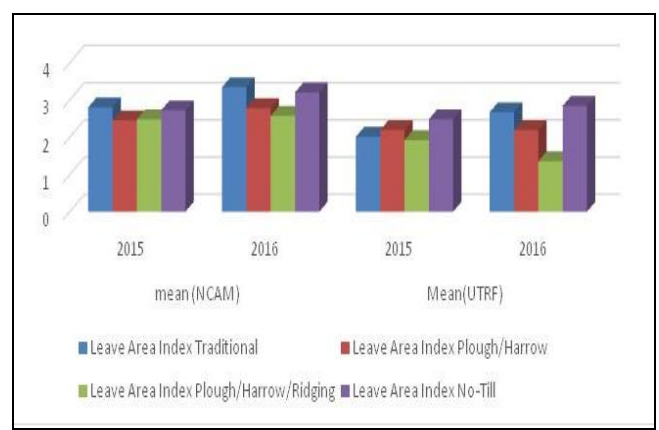

Figure 8. Mean Leave Area Index on Different Tillage Type in UTRF and NCAM Experimental Site Source: Author's fieldwork (2016)

\section{Impact of Tillage Methods on Maize Yield Parameters}

Table 3 shows that there was no significant impact of the tillage methods on maize height on the UTRF experimental site in 2015 and 2016 (p value $(0.705)>0.05$ and p value $(0.562)>$ 0.05 respectively). For the NCAM site, there was no significant impact of the tillage methods on maize height in 2015 ( $p$ value $(0.317)<0.05)$ but there is a significant impact of the tillage methods on maize height in 2016 ( $\mathrm{p}$ value $(0.01)<0.05)$. Hence, tillage methods do affect the maize height although a remarkable effect was not marked between 2015 and 2016.

Table 3. Tillage Impact on Maize Height (Data sources: Author's fieldwork, 2016)

\begin{tabular}{|l|l|l|l|l|l|l|l|l|l|l|l|}
\hline \multirow{2}{*}{ SN } & \multirow{2}{*}{ Sites } & \multicolumn{2}{|c|}{ Sum of Squares } & \multicolumn{2}{|c|}{ Df } & \multicolumn{2}{c|}{ Mean Square } & \multicolumn{2}{|c|}{ F } & \multicolumn{2}{c|}{ Sig. } \\
\cline { 3 - 13 } & & 2015 & 2016 & 2015 & 2016 & 2015 & 2016 & 2015 & 2016 & 2015 & 2016 \\
\hline 1 & UTRF & .094 & .310 & 3 & 3 & .031 & .103 & .481 & .731 & .705 & .562 \\
2 & NCAM & .087 & 2.186 & 3 & 3 & .029 & .729 & 1.381 & 27.721 & .317 & .001 \\
\hline
\end{tabular}

For the number of leaves, there was no significant impact of the tillage methods on the number of maize leaves on UTRF experimental plot in 2015 and 2016 with p value $(0.104)>0.05$ and $p$ value $(0.171)>0.05$ respectively as shown in table 4 . On NCAM experimental site, there was no significant impact of the tillage methods on the number of maize leaves in 2015 (p value 
$(0.106)>0.05)$ but there is a significant impact in 2016 ( $\mathrm{p}$ value $(0.001)<0.05$ ). This implies that the tillage methods do affect the number of leaves although a remarkable effect was not marked between 2015 and 2016.

Table 4. Tillage Impact on Number of Maize Leaves

(Data sources: Author's fieldwork, 2016)

\begin{tabular}{|c|c|c|c|c|c|c|c|c|c|c|c|}
\hline \multirow{2}{*}{ SN } & \multirow{2}{*}{ Sites } & \multicolumn{2}{|c|}{ Sum of Squares } & \multicolumn{2}{|c|}{ Df } & \multicolumn{2}{|c|}{ Mean Square } & \multicolumn{2}{|c|}{$\mathrm{F}$} & \multicolumn{2}{|c|}{ Sig. } \\
\hline & & 2015 & 2016 & 2015 & 2016 & 2015 & 2016 & 2015 & 2016 & 2015 & 2016 \\
\hline 1 & UTRF & 3.583 & 10.25 & 3 & 3 & 1.194 & 3.417 & 2.867 & 2.158 & .104 & .171 \\
\hline 2 & NCAM & 4.250 & 34.25 & 3 & 3 & 1.417 & 11.417 & 2.833 & 22.83 & .106 & .001 \\
\hline
\end{tabular}

Furthermore, table 5 shows that there was no significant impact of the tillage methods on the maize leaf length at the UTRF experimental site in 2015 and 2016 (p values $(0.418)>0.05$ and $\mathrm{p}$ value $(0.555)<0.05$ respectively). On NCAM experimental site, there was no significant impact of the tillage methods on the maize leaf length in 2015 and 2016 (p value $(0.176)>0.05$ and $p$ value $(0.072)<0.05)$. Hence, tillage methods do not affect the maize leaf length between 2015 and 2016 and at both locations.

Table 5. Tillage Impact on Maize Leave Length

(Data sources: Author's fieldwork, 2016)

\begin{tabular}{|c|c|c|c|c|c|c|c|c|c|c|c|}
\hline \multirow{2}{*}{$\mathrm{SN}$} & \multirow{2}{*}{ Sites } & \multicolumn{2}{|c|}{ Sum of Squares } & \multicolumn{2}{|c|}{ Df } & \multicolumn{2}{|c|}{ Mean Square } & \multicolumn{2}{|c|}{$\mathrm{F}$} & \multicolumn{2}{|c|}{ Sig. } \\
\hline & & 2015 & 2016 & 2015 & 2016 & 2015 & 2016 & 2015 & 2016 & 2015 & 2016 \\
\hline 1. & UTRF & .020 & .021 & 3 & 3 & .007 & .007 & 1.602 & .744 & .418 & .555 \\
\hline 2. & NCAM & 036 & .079 & 3 & 3 & .012 & .026 & 2.118 & .3445 & .176 & .072 \\
\hline
\end{tabular}

Table 6 reveals that there was no significant impact of the tillage methods on the maize leave width on the UTRF experimental site in 2015 and 2016 (p values $(0.837)>0.05$ and $p$ value $(0.116)>0.05)$. On NCAM experimental site, there was no significant impact of the tillage methods on maize leaf width in 2015 (p value $(0.562)>0.05$ ) while in 2016, there was significant impact of the tillage methods on Maize leaf width $(\mathrm{p}$ value $(0.001)<0.05)$. The implication of this result is that tillage methods do affect the maize leave width although a remarkable effect was not marked between 2015 and 2016.

Table 6. Tillage Impact on Maize Leave Width

(Data sources: Author's fieldwork, 2016)

\begin{tabular}{|c|c|c|c|c|c|c|c|c|c|c|c|}
\hline \multirow{2}{*}{ SN } & \multirow{2}{*}{ Sites } & \multicolumn{2}{|c|}{ Sum of Squares } & \multicolumn{2}{|c|}{ Df } & \multicolumn{2}{|c|}{ Mean Square } & \multicolumn{2}{|c|}{$\mathrm{F}$} & \multicolumn{2}{|c|}{ Sig. } \\
\hline & & 2015 & 2016 & 2015 & 2016 & 2015 & 2016 & 2015 & 2016 & 2015 & 2016 \\
\hline 1. & UTRF & .075 & 1.947 & 3 & 3 & .025 & .649 & .282 & 2.704 & .837 & .116 \\
\hline 2. & NCAM & .191 & 5.057 & 3 & 3 & .064 & 1.686 & .731 & 24.079 & .562 & .001 \\
\hline
\end{tabular}

In addition, table 7 reveals that leave area index across the four-tillage type (T, PH, PHR and NT) are not significantly different in 2015, but they are significantly different in 2016 with p value $(0.134)>0.05$ and $(0.003)<0.05$ respectively. The result indicated that leave area index were independent of tillage types at UTRF experimental site in 2015, but are influenced by tillage type in 2016. Also, the leave area index across the four tillage types (T, PH, PHR and NT) were not significantly different at NCAM experimental site in both 2015 and 2016 with p value $(0.651$ and 0.396) > 0.05. It implies that tillage type has no significant impact on leave area index in 2015 and 2016 at NCAM experimental site. Maize leaf area is of importance to photosynthesis and yield. The photosynthetic capacity of crops is a function of leaf area. Leaf area is important for crop light interception and therefore has a large influence on crop yield. The findings in 2016 is in agreement with Sullivan (2003) as cited in Karuma et al., (2016) who reported higher LAI values in maize cultivated under conventional tillage and attributed this to improved access to soil moisture as compared to no-till. Thus, higher LAI results in better ground cover for lesser soil 
water evaporation and increased weed suppression. Therefore, the differences in maize LAI under the different tillage practices can also be attributed to the differences in exploration of the maize roots for soil moisture in the soil profile.

Table 7. Tillage Impact on Leave Area Index

\begin{tabular}{|c|c|c|c|c|c|c|c|c|c|c|c|}
\hline \multirow{2}{*}{ SN } & \multirow{2}{*}{ Sites } & \multicolumn{2}{|c|}{ Sum of Squares } & \multicolumn{2}{|c|}{ Df } & \multicolumn{2}{|c|}{ Mean Square } & \multicolumn{2}{|c|}{$\mathrm{F}$} & \multicolumn{2}{|c|}{ Sig. } \\
\hline & & 2015 & 2016 & 2015 & 2016 & 2015 & 2016 & 2015 & 2016 & 2015 & 2016 \\
\hline 1 & UTRF & .558 & 3.982 & 3 & 3 & .186 & 1.327 & 2.490 & 11.857 & .134 & $.003 *$ \\
\hline 2 & NCAM & .264 & 1.152 & 3 & 3 & .088 & .384 & .569 & 1.123 & .651 & .396 \\
\hline
\end{tabular}

For crop yield, table 8 shows that the regression model for the tillage methods significantly impacted on crop yield in 2015 but not in 2016 on the UTRF experimental site with a coefficient of determination of $59.3 \%$ for 2015 which is relatively high and $43.3 \%$ for 2016 respectively. This further shows that there is a strong relationship and it is statistically positive with $\mathrm{r}^{2}=0.593$. This implies that an improvement on the tillage methods will bring about increase to the maize yield in 2015 on UTRF site only. There is a relatively weak relationship and statistically positive with $\mathrm{r}^{2}=0.433$ between maize yield and tillage methods. This also implies that the tillage methods improves maize yield in 2016 as shown by the research findings in the experimental farm. The Turkey test for 2015 further shows that on UTRF experimental plots, PH yield $>$ NT yield ( $\mathrm{p}$ value $(0.015)<0.05)$, PH yield $>$ T yield $(\mathrm{p}$ value $(0.04)<0.05)$ while PH and PHR are not statistically different in crop yield. The Turkey test for 2016 shows that on UTRF experimental plot, T yield > NT yield $(\mathrm{p}$ value $(0.042)<0.05)$ while there is no significant difference between the other treatment plots.

Table 8. Impact of Tillage Methods on Crop Yield in UTRF Experimental Plot

(Data sources: Author's fieldwork, 2016)

\begin{tabular}{|c|c|c|c|c|c|c|c|c|c|c|}
\hline Source & Type III Sum c & Squares & Df & & Mean Square & & $F$ & & Sig. & \\
\hline & 2015 & 2016 & 2015 & 2016 & 2015 & 2016 & 2015 & 2016 & 2015 & 2016 \\
\hline Corrected Model & $2223333.333 a$ & $684266.667 \mathrm{~b}$ & 3 & 3 & 741111.111 & 228088.889 & 6.352 & 3.801 & .016 & .058 \\
\hline Intercept & 31363333.333 & 9434133.333 & 1 & 1 & 31363333.333 & 9434133.333 & 268.829 & 157.236 & .000 & .001 \\
\hline Tillage Type & 2223333.333 & 684266.667 & 3 & 3 & 741111.111 & 228088.889 & 6.352 & 3.801 & .016 & .058 \\
\hline Error & 933333.333 & 480000.000 & 8 & 8 & 116666.667 & 60000.000 & & & & \\
\hline Total & 34520000.000 & 10598400.000 & 12 & 12 & & & & & & \\
\hline Corrected Total & 3156666.667 & 1164266.667 & 11 & 11 & & & & & & \\
\hline
\end{tabular}

a. $\quad$ Dependent Variable: Crop Yield, R Squared $=.704$ (Adjusted R Squared $=.593$ )

b. $\quad$ R Squared $=.588$ (Adjusted R Squared $=.433$ )

On NCAM experimental plot, the tillage methods significantly impact on crop yield in 2015 but not in 2016 with a coefficient of determination of $54.7 \%$ which is relatively high and $1.1 \%$ respectively as shown in table 6-9. This shows that there is a strong relationship and direct that is statistically positive with $\mathrm{r}^{2}=0.547$ between tillage methods and maize yield at NCAM Plot. This implies that the tillage methods improve maize yield only in 2015 on NCAM site. There is a very weak direct relationship and but statistically positive with $\mathrm{r}^{2}$ $=0.011$ between the tillage methods and maize yield because there are other environmental factors which contributed largely to the maize yield at the expense of the tillage methods in the area. This also implies that the tillage methods improves maize yield in 2016 as shown by the research findings in the experimental farm. The Turkey test for 2015 on NCAM shows that $\mathrm{PH}$ yield $>\mathrm{T}$ yield $(\mathrm{p}$ value $(0.026)<0.05)$. Also, $\mathrm{PH}$ yield $>$ PHR yield ( $\mathrm{p}$ value $(0.046)$ $<0.05)$ which is statistically significant. There is no statistical difference in maize yield between PH and NT. The Turkey test for 2016 experimental treatment revealed that there is no significant difference between all the treatment plots.

The SWAT analysis generated three (3) hydrological response units (HRU) each for the two study areas. The HRU is the smallest spatial unit of the model because it lumps all similar land use, soil, elevation profile, and slope within a sub basin based on user defined threshold. Shown in 
tables 2 is the distribution of the HRU in UTRF and NCAM sub catchments. Figure 2 shows a schematic representation of the hydrologic cycle modeled in SWAT for the study areas.

Table 9. Impact of Tillage Methods on Crop Yield in NCAM Experimental Plot

(Data sources: Author's fieldwork, 2016)

\begin{tabular}{|c|c|c|c|c|c|c|c|c|c|c|}
\hline Source & Type III Sum & of Squares & Df & & Mean Square & & $\mathrm{F}$ & & Sig. & \\
\hline & 2015 & 2016 & 2015 & 2016 & 2015 & 2016 & 2015 & 2016 & 2015 & 2016 \\
\hline Corrected Model & $1589166.667 \mathrm{a}$ & $71466.667 \mathrm{~b}$ & 3 & 3 & 529722.222 & 23822.222 & 5.433 & .961 & .025 & .457 \\
\hline Intercept & 7520833.333 & 4514133.333 & 1 & 1 & 7520833.333 & 4514133.333 & 77.137 & 182.02 & .000 & .000 \\
\hline Tillage Type & 1589166.667 & 71466.667 & 3 & 3 & 529722.222 & 23822.222 & 5.433 & .961 & .025 & .457 \\
\hline Error & 780000.000 & 198400.000 & 8 & 8 & 97500.000 & 24800.000 & & & & \\
\hline Total & 9890000.000 & 4784000.000 & 12 & 12 & & & & & & \\
\hline Corrected Total & 2369166.667 & 269866.667 & 11 & 11 & & & & & & \\
\hline
\end{tabular}

a. $\quad$ Dependent Variable: Crop Yield, R Squared = .671 (Adjusted R Squared = .547)

b. $\quad$ R Squared $=.265$ (Adjusted R Squared $=.011)$

Table 10. Distribution of the HRU in UTRF and NCAM sub catchments

\begin{tabular}{|c|c|c|c|c|}
\hline Name & Sub basin & Hydrologic Response Unit & Land Area Covered (m2) & Tillage method \\
\hline UTRF & 18 & 44 & 0.463 & PH \\
\hline UTRF & 18 & 45 & 0.201 & NT, T \\
\hline UTRF & 18 & 46 & 0.209 & PHR \\
\hline NCAM & 42 & 103 & 0.872 & NT ,T \\
\hline NCAM & 42 & 104 & 2.19 & PH \\
\hline NCAM & 42 & 105 & 2.56 & PHR \\
\hline
\end{tabular}

*NOTE: T-Traditional heap, PH-Plough/Harrow, PHR-Plough/Harrow/Ridge, NT-No Till

In simulating the impact of the different tillage methods, Soil Water Assessment $\mathrm{T}$ model for both UTRF and NCAM experimental plots are 17.27 and 16.09 metric tons/ha. On UTRF site, NT, T and PHR treatment plots had the same value of 4.32 metric tons/ha while PH plot had 4.31 metric tons/ha. On NCAM experimental plot, all the tillage types had the same value of 4.03 metric tons/ha as shown in table 11. The modeled summary for crop yield is shown in figure 5. According to Aina (2011), No-tillage has proven to be an attractive alternative for maize (Zea mays L.) and other row crops on coarse-textured soils in the humid' and subhumid tropics while in the semi-arid region with fine textured soils, some type of conventional tillage system of mechanical seedbed preparation (plowing and harrowing) is necessary. The frequency and type of mechanical operation desired depends on soil characteristics and the crops to be grown.

The observations reveal that Plough/Harrow tillage method is the most suitable for optimum crop yield in maize production in this ecological zone. Therefore, the application of this tillage type by farmers in the study area is expected to give increased maize yield as well as conserve water and soil quality. Furthermore, the variations experienced between the two planting seasons in the crop yield on UTRF and NCAM experimental sites are probably due to innate soil properties, texture, structure, type of soil, weather variability among others. Lal (1986) observed increased maize grain yields on plots with no-till treatment $(2.5 \mathrm{t}$ ha-1) compared with the plow-till treatment (2.0 t ha-1) in southwest Nigeria. Also, Agbede et al., (2008), Obalum et al., (2011), and Senjobi et al., (2013) had different conclusion in their studies that traditional tillage system resulted in the most favorable soil environment, for crop growth and best performance of crop followed by conventional and no-tillage system and concluded that tillage methods have the capability to increase production while no-tillage is better under long term production for sustainable land use. 


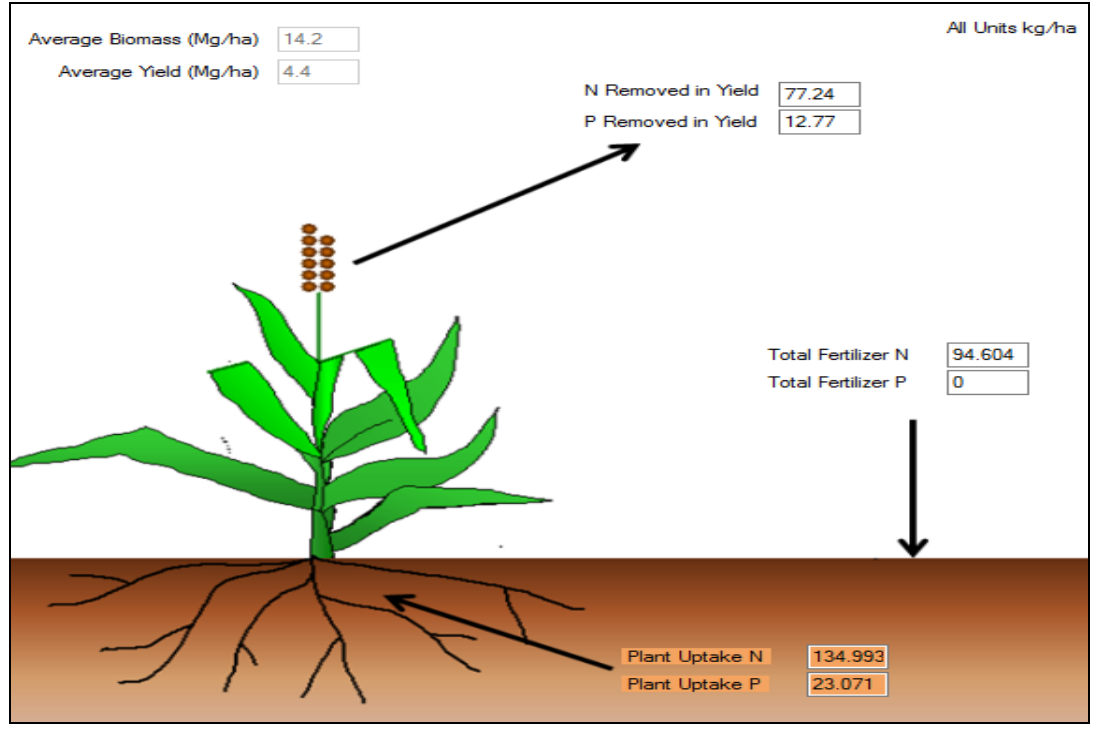

Figure 5. SWAT modeled summary for crop yield in the study area Source: Author's fieldwork (2017)

Table 11. Crop/harvest yield in the study area Source: Author's fieldwork (2016)

\begin{tabular}{|c|c|c|}
\hline Tillage types & UTRF & NCAM \\
\hline PH & 4.31 & 4.03 \\
\hline NT & 4.32 & 4.03 \\
\hline T & 4.32 & 4.03 \\
\hline PHR & 4.32 & 4.03 \\
\hline Grand total (metric tons/ha) & 17.27 & 16.09 \\
\hline
\end{tabular}

\section{CONCLUSION AND RECOMMENDATION}

The study concludes that the different tillage methods impact on the crop yield, however, Plough/Harrow had comparatively favorable effect on the soil environment, contribution to surface runoff and crop yield. It is therefore recommended Plough/Harrow should be adopted for a sustainable environment due to its comparatively favorable effect on the soil environment, contribution to surface runoff and crop yield in this ecological zone.

\section{REFERENCES}

Agbede, T.M., Ojeniyi, S.O., \& Adeyemo, A.J. (2008). Effect of poultry manure on soil physical and chemical properties, growth and grain yield of sorghum in southwest, Nigeria. American-Eurasian journal of sustainable agriculture, 2(1), 72-77.

Ahaneku, I.E. (2010). Conservation of soil and water resources for combating food crisis in Nigeria. Scientific Research and Essays, 5(6), 507-513.

Ahmed, Y.A. (2009). Settlements pattern and functional distribution in an emerging communities: a case of a local government area of Kwara State, Nigeria. The social sciences, 4(3), 256-263.

Aina, P.O. (2011). Conservation Tillage for Sustainable Agricultural Productivity, 'Tillage for Agricultural Productivity and Environmental Sustainability' Lead Paper - International Soil Tillage Research Organization (ISTRO)Nigerian Symposium Conference, held in Ilorin, Nigeria, February 21-23 2011.

Amir, K. \& Theodor, F. (2012). An Ecologically Sustainable Approach to Agricultural Production Intensification: Global Perspectives and Developments, Field Actions Science Reports [Online], Special Issue 6 http://factsreports.revues.org/1382 
Cook, R.L., \& Trlica, A. (2016). Tillage and fertilizer effects on crop yield and soil properties over 45 years in southern Illinois. Agronomy Journal, 108(1), 415-426.

Derpsch, R., Friedrich, T., Kassam, A., \& Li, H. (2010). Current status of adoption of no-till farming in the world and some of its main benefits. International Journal of Agricultural and Biological Engineering, 3(1), 1-25.

FAO (2008). Towards Alleviation of Poverty in the Tropics: An International Technical Workshop on Investing in Sustainable Crop Intensification: The Case for Improving Soil Health. Proceedings FAO, Rome: 22-24.

Giller, K.E., Witter, E., Corbeels, M., \& Tittonell, P. (2009). Conservation agriculture and smallholder farming in Africa: the heretics' view. Field crops research, 114(1), 23-34.

IAASTD (2009). International Assessment of Agricultural Knowledge. Science and Technology for Development, Global Report; pp.606, Washington DC.

IPCC (2007). Climate Change 2007, Fourth Assessment report of the Intergovernmental Panel on Climate Change, Cambridge University Press.

Herman G.V. (2010). Structure and share of agricultural lands, key indicators in quantifying the anthropogenic impact in the Somes Plain. Analele Universităţii din Oradea Fascicula Construcţii şi Instalaţii Hidroedilitare, 13(2): 153-159.

Karuma, A.N., Gachene, C.K.K, Gicheru, P.T., Mtankwa, P.W., \& Amuri, N. (2016). Effect of Tillage and Cropping Systems on Miaze and Beans Yield and Selected Components in a Semi-Arid Area of Kenya. Tropical and Subtropical Agroecosystems, 19 (2):167-179.

Lal, R. (1989). Cropping systems effects on runoff, erosion, water quality, and properties of a savanna soil at Ilorin, Nigeria. IAHS-AISH publication, (184), 67-74.

Mostaghimi, S., Deizman, M.M., Dillaha, T.A., Heatwole, C.D., \& Perumpral, J.V. (1988). Tillage effects on runoff water quality from sludge-amended soils. Bulletin 162 Virginia Water Resources Research Center, Virginia Polytechnic Institute and State University, Blacksburg.

Mustapha, K.M. (2008). Assessment of Water Quality of Oyun Reservoir, Offa, Nigeria, using Selected Physic-Chemical Parameters. Turkish Journal of Fisheries and Aquatic Sciences 8(2):309-319

Obalum, S.E., Amana, S.M., Obi, M.E., \& Akatsuki, T. (2011). Agronomic Responses to Four Tillage Variants on a Sandyloam Ultisol Cropped to Sorghum and Soybean in the Derived Savanna of Southeastern Nigeria, Exp.Agric, 404418.

Ohu, J.O. (2011).Tillage for Agricultural Productivity and Environmental Sustainability, Conference, Keynote address held in Ilorin, Nigeria, from February 21-23 2011.

Senjobi, B.A., Ande, O.T., \& Okulaja, A.E. (2013). Effects of Tillage Practices on Soil Properties under Maize Cultivation on OxicPaleustalf in South Western Nigeria. Open Journal of Soil Science, 3,163-168.

Submitted:

July 16,2018
Revised:

January 08, 2019
Accepted and published online March 13, 2019 